Hasil Pemeriksaan TB Paru Metode TCM pada Tersangka TB Paru

\title{
Results of the TCM Method of Pulmonary Tuberculosis Examination on Lung TB Suspects
}

\section{MUHAJIR}

\author{
Rumah Sakit Tidar Magelang \\ Jl Tidar No 30 A Magelang, Jawa Tengah \\ Email:muhajir21@yahoo.com
}

\begin{abstract}
Abstrak
Tuberkulosis (TB) ialah suatu penyakit infeksi yang disebabkan oleh bakteri Mycobacterium tuberculosis (MTB). Determinan penyakit TB paru antara lain meliputi jenis kelamin, dan usia. Metode Tes Cepat Molekuler (TCM) merupakan terobosan program TB untuk pasien TB Resisten Obat. Metode TCM membutuhkan waktu dua jam untuk mendapatkan hasil diagnosis pasien. Metode TCM untuk mendiagnosis TB dan resistensi terhadap rifampisin secara cepat dan akurat. RSUD Tidar Magelang merupakan salah satu tempat rujukan pemeriksaan TCM dari berbagai fasyankes. Tujuan penelitian ini untuk mengetahui gambaran hasil pemeriksaan TB paru metode TCM pada tersangka TB paru di RSUD Tidar Magelang. Jenis penelitian deskriptif. Data penelitian merupakan data sekunder yang diperoleh dari RSUD Tidar Magelang.Berdasarkan usia yaitu remaja awal, remaja akhir, dewasa awal, dewasa akhir, lansia awal, lansia akhir, dan manula hasil rif sensitif $0,76 \%$, $11,45 \%, 9,54 \%, 7,25 \%, 5,73 \%, 8,78 \%$ dan $3,82 \%$. Hasil negatif $1,15 \%, 1,91 \%, 6,87 \%$, $7,25 \%, 7,63 \%, 14,89 \%$ dan $12,98 \%$. Hasil rif sensitif pada laki-laki $27,1 \%$ dan perempuan $20,23 \%$. Hasil negatif pada laki-laki $31,3 \%$ dan perempuan $21,37 \%$. Hasil rif sensitif paling banyak daerah Magelang, diikuti Kota Magelang, kemudian Kodya Jakarta Timur, Banjarnegara dan Purworejo. Hasil negatif dijumpai pada Magelang, diikuti Kota Magelang, kemudian Wonosobo dan Kota Waringin Timur.
\end{abstract}

Kata Kunci : TB Paru ; TCM ; Usia ; Jenis Kelamin

\begin{abstract}
Tuberculosis (TB) is an infectious disease caused by the bacterium Mycobacterium tuberculosis (MTB). Determinants of pulmonary TB disease include gender, and age. The Rapid Molecular Test Method (TCM) is a breakthrough TB program for Drug Resistant TB patients. The TCM method takes two hours to get the patient's diagnosis. TCM method for diagnosing TB and resistance to rifampin quickly and accurately. Tidar Magelang Hospital is one of the referral places for TCM examinations from various health facilities. The purpose of this study was to describe the results of the TCM method of pulmonary TB examination on pulmonary TB suspects at Tidar Magelang Hospital. This type of research is descriptive. The research data is secondary data obtained from Tidar Hospital Magelang. Based on age, namely early adolescence, late adolescence, early adulthood, late adulthood, early elderly, late elderly, and seniors, the results were sensitive rif $0.76 \%, 11.45 \%, 9,54 \%$, $7.25 \%, 5.73 \%, 8.78 \%$ and $3.82 \%$. Negative results $1.15 \%, 1.91 \%, 6.87 \%, 7.25 \%, 7.63 \%$, $14.89 \%$ and $12.98 \%$. The rif results were sensitive to $27.1 \%$ males and $20.23 \%$ females. Negative results in $31.3 \%$ men and $21.37 \%$ women. The most sensitive rif results are in Magelang, followed by Magelang City, then East Jakarta Municipality, Banjarnegara and Purworejo. Negative results were found in Magelang, followed by Magelang City, then Wonosobo and East Waringin City.
\end{abstract}

Keywords: Pulmonary TB ; TCM ; Age ; Gender 


\section{Pendahuluan}

Tuberkulosis (TB) merupakan penyakit yang dijuluki sebagai penyakit infeksi bacterial pembunuh utama di dunia. Mycobacterium tuberculosis (M. Tuberculosis) merupakan bakteri penyebab penyakit. Pasien tuberkulosis dengan BTA positif melalui percik renik dahak (droplet nuclei) yang dikeluarkannya merupakan sumber penularan penyakit TB. Jika seseorang menghirup udara dengan kandungan percik renik dari dahak yang infeksisus maka akan menyebabkan seseorang terinfeksi oleh penyakit TB (Hastuti, 2017).

Gambaran klinis yang timbul tidak spesifik menyebabkan diagnosis awal untuk TB sangat sulit untuk dilakukan. Beberapa macam pemeriksaan untuk diagnosis TB adalah pemeriksaan gejala klinis yaitu pemeriksaan laboratoris dan pemeriksaan fisik radiologis. Seseorang disebut positif TB jika ditemukannya M.tuberculosis pada pemeriksaan biakaan dahak ataupun kultur. Teknik kultur merupakan metode dengan sensitivitas dan spesifisitas yang tinggi hanya membutuhkan waktu lama untuk memperoleh hasilnya, biasanya lebih dari satu minggu. Tidak hanya itu, juga dibutuhkan tenaga yang memiliki kompetensi khusus untuk dapat mengerjakan. Penemuan M. tuberculosis dilakukan menggunakan pewarnaan Ziehl Nielsen dengan pembacaan mikroskop binokuler. Sehungga, dibutuhkan metode yang tepat, cepat, sensitif dan spesifik untuk menegakkan diagnosis TB Paru (Evita, 2019).

Metode Tes Cepat Molekuler (TCM) adalah pembaharuan program TB untuk kasus pasien dengan TB Resisten Obat. Lama pemeriksaan metode TCM adalah selama dua jam untuk mendapatkan hasil diagnosis. Keunggulan metode TCM adalah sensitif dan spesifik sehingga mampu untuk menemukan M.tuberculosis dan resistensi terhadap rifampisin secara simultan. TCM ini hanya bisa digunakan unutk diagnosis TB dan resistensi terhadap rifampisin secara cepat dan akurat, akan tetapi tidak bisa digunakan sebagai monitoring/ pemeriksaan lanjutan pada pasien yang sedang menjalani terapi pengobatan (Kementerian Kesehatan, 2017).

Alat TCM yang saat ini digunakan adalah Xpert MTB/RIF. Rekomendai World Health Organization (WHO) yaiut pemakaian GeneXpert digunakan sebagai evaluasi pasien tersangka TB MDR (Multi Drug Resistance) juga untuk pasien dengan BTA negatif. GeneXpert bisa dijadikan diagnosis awal TB dan sebagai kepastian untuk diagnosis secara cepat kepada pasien secara keseluruhan (Hafidzah, 2018).

\section{Metode}

Penelitian ini menggunakan desain deskriptif non eksperimental dengan kriteria penelitian deskriptif. Jenis penelitian ini bertujuan untuk melihat gambaran hasil pemeriksaan TB paru dengan metode TCM pada tersangka TB paru. Pada penelitian ini menggunakan rancangan cross sectional. Pengambilan data menggunakan data rekam medik pada pasien tersangka TB paru di Laboratorium RSUD Tidar Magelang. Subjek penelitian ini adalah data pasien dan hasil pemeriksaan TCM pada tersangka TB paru selama tahun 2019 dengan didapatkan data sekitar 262 sampel yang berasal dari berbagai puskesmas/instansi rujukan. Data penelitian meliputi asal sampel, jenis kelamin, usia, dan hasil pemeriksaan TCM.

\section{Hasil dan Pembahasan}

Hasil penelitian diperoleh laki-laki 153 orang, dan perempuan 109 orang. Usia pasien paling muda 15 tahun, dan paling tua 88 tahun. Usia pasien dibagi dalam 7 kelompok usia sesuai standar Depkes (2009) meliputi remaja awal ( $<15$ tahun), remaja akhir (17-25 tahun), dewasa awal (26-35 tahun), dewasa akhir (36-45 tahun), lansia awal (46-55 tahun), lansia akhir (56-65 tahun) dan manula (> 65 tahun). 
Tabel 1 Karakteristik pasien berdasar jenis kelamin dan usia

\begin{tabular}{lcccccc}
\hline Kelompok & \multicolumn{2}{c}{ laki-laki } & \multicolumn{2}{c}{ perempuan } & \multicolumn{2}{c}{ jumlah } \\
usia & $\mathrm{n}$ & $\%$ & $\mathrm{n}$ & $\%$ & $\mathrm{n}$ & $\%$ \\
\hline rewaja awal & 2 & 0,76 & 3 & 1,15 & 5 & 1,91 \\
remaja akhir & 17 & 6,49 & 18 & 6,87 & 35 & 13,36 \\
dewasa awal & 21 & 8,02 & 22 & 8,40 & 43 & 16,41 \\
dewasa akhir & 20 & 7,63 & 18 & 6,87 & 38 & 14,50 \\
lansia awal & 25 & 9,54 & 10 & 3,82 & 35 & 13,36 \\
lansia akhir & 38 & 14,50 & 24 & 9,16 & 62 & 23,66 \\
manula & 30 & 11,45 & 14 & 5,34 & 44 & 16,79 \\
jumlah & 153 & 58,40 & 109 & 41,60 & 262 & 100,00 \\
\hline
\end{tabular}

Tabel 1 menyebutkan bahwa jumlah pasien paling banyak dari kelompok lansia akhir laki-laki $(14,50 \%)$, dan perempuan $9,16 \%$. Jumlah pasien paling sedikit adalah remaja awal.

Data penelitian hasil pemeriksaan metode TCM pasien tersangka TB paru dideskripsikan berdasar usia. Hasil pemeriksaan TCM diperoleh rif sensitif dan negatif. Rif negatif artinya $M$. tuberculosis (MTB) terdeteksi, negatif artinya MTB tidak terdeteksi.

Tabel 2 Deskripsi hasil pemeriksaan metode TCM berdasarkan usia

\begin{tabular}{lllllll}
\hline Kelompok usia & \multicolumn{2}{l}{ Rif sensitive } & Negatif & Jumlah & \\
& $\mathrm{n}$ & $\%$ & $\mathrm{n}$ & $\%$ & $\mathrm{n}$ & $\%$ \\
\hline rewaja awal & 2 & 0,76 & 3 & 1,15 & 5 & 1,91 \\
remaja akhir & 30 & 11,45 & 5 & 1,91 & 35 & 13,36 \\
dewasa awal & 25 & 9,54 & 18 & 6,87 & 43 & 16,41 \\
dewasa akhir & 19 & 7,25 & 19 & 7,25 & 38 & 14,50 \\
lansia awal & 15 & 5,73 & 20 & 7,63 & 35 & 13,36 \\
lansia akhir & 23 & 8,78 & 39 & 14,89 & 62 & 23,66 \\
manula & 10 & 3,82 & 34 & 12,98 & 44 & 16,79 \\
jumlah & 124 & 47,33 & 138 & 52,67 & 262 & 100,00 \\
\hline
\end{tabular}

Tabel 2 menyebutkan bahwa hasil pemeriksaan TCM negatif lebih banyak dijumpai $(52,67 \%)$ dibanding hasil rif sensitif (47,33\%). Hasil TCM negatif paling banyak ditemukan pada lansia akhir. Hasil rif sensitif paling banyak ditemukan pada remaja akhir.

Gambar 1 Grafik hasil pemeriksaan metode TCM berdasarkan usia

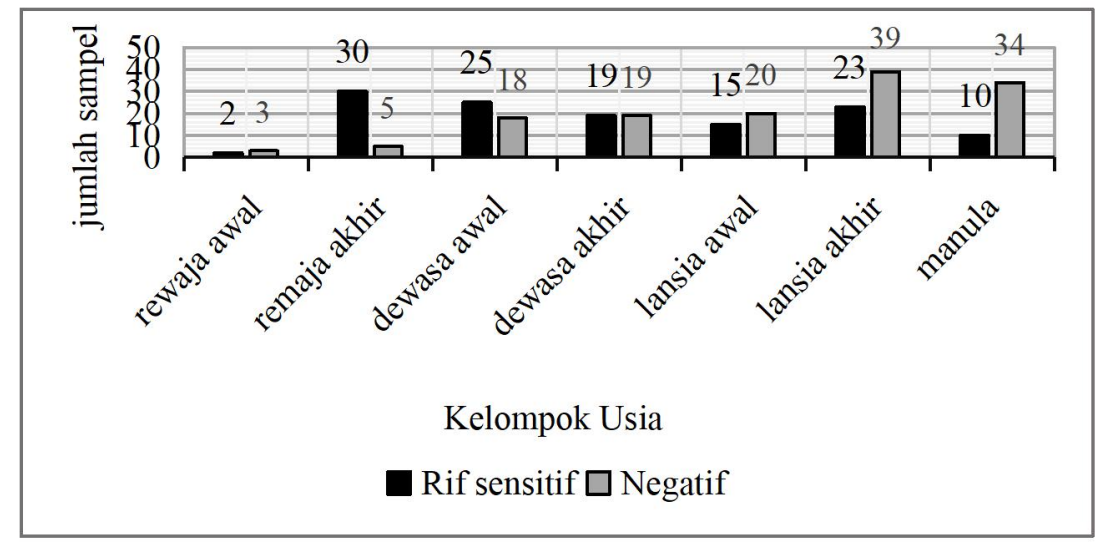


Gambar 1 memperlihatkan jumlah sampel dengan hasil pemeriksaan TCM negatif terdapat pada semua kelompok usia. Jumlah negatif paling banyak pada lansia akhir. Hasil rif sensitif paling banyak ditemui pada remaja akhir.

Tabel 3 Hasil pemeriksaan metode TCM berdasarkan jenis kelamin

\begin{tabular}{lllllll}
\hline Jenis & \multicolumn{2}{l}{ Rif sensitive } & \multicolumn{2}{l}{ Negatif } & \multicolumn{2}{l}{ Jumlah } \\
kelamin & $\mathrm{N}$ & $\%$ & $\mathrm{n}$ & $\%$ & $\mathrm{n}$ & $\%$ \\
& $\mathrm{~N}$ & 27,10 & 82 & 31,30 & 153 & 58,40 \\
laki-laki & 71 & 20,23 & 56 & 21,37 & 109 & 41,60 \\
perempuan & 53 & 47,33 & 138 & 52,67 & 262 & 100,00 \\
jumlah & 124 & \multicolumn{7}{l}{}
\end{tabular}

Data penelitian hasil pemeriksaan metode TCM pasien tersangka TB Paru dideskripsikan berdasar jenis kelamin. Tabel 3 menyebutkan bahwa hasil pemeriksaan TCM pada sebagian besar laki-laki $(31,30 \%)$ adalah negatif, hasil rif sensitif sebesar $27,10 \%$. Hasil TCM pada perempuan sebagian besar juga negatif $(21,37 \%)$, hasil rif sensitif sebesar $20,23 \%$.

Gambar 2 Grafik hasil pemeriksaan TCM berdasar Jenis Kelamin

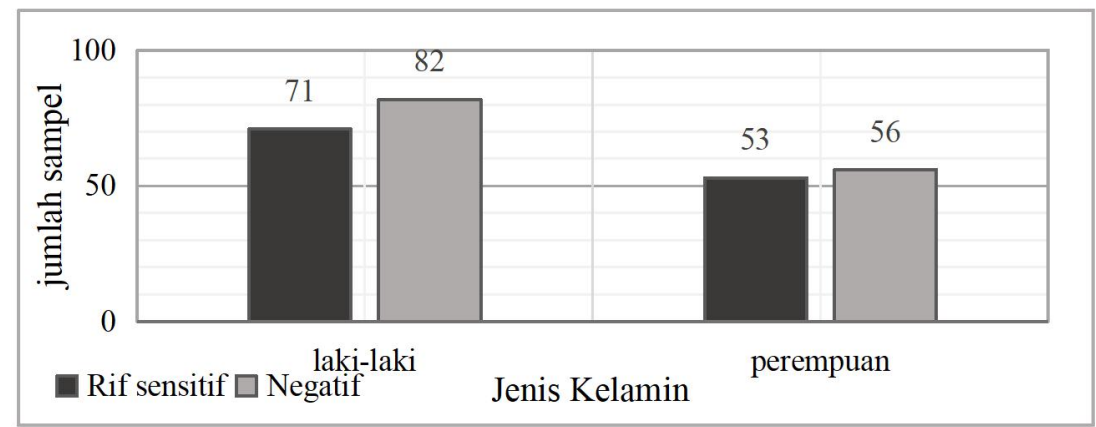

Gambar 2 memperlihatkan pada laki-laki hasil pemeriksaan TCM negatif 82 sampel, rif sensitif 71 sampel. Pemeriksaan TCM pada perempuan diperoleh hasil negatif s 56 sampel, rif sensitif 53 sampel.

Sampel pemeriksaan tersangka TB paru berasal dari berbagai fasyankes. Sampel yang dikirim dilengkapi dengan data pasien dan instansi pengirim.

Tabel 4 Distribusi frekuensi hasil TCM berdasar asal daerah sampel pasien TB paru

\begin{tabular}{lllllll}
\hline Asal sampel & \multicolumn{2}{l}{ Rif sensitif } & Negatif & \multicolumn{3}{l}{ Jumlah } \\
& $\mathrm{n}$ & $\%$ & $\mathrm{n}$ & $\mathrm{\%}$ & $\mathrm{n}$ & $\%$ \\
\hline $\begin{array}{l}\text { Kodya Jakarta } \\
\text { Timur }\end{array}$ & 1 & 0,38 & 0 & 0,00 & 1 & 0,38 \\
$\begin{array}{l}\text { Kota Magelang } \\
\text { Magelang }\end{array}$ & 31 & 11,83 & 28 & 10,69 & 59 & 22,52 \\
$\begin{array}{l}\text { Wonosobo } \\
\text { Kota Waringin }\end{array}$ & 0 & 34,35 & 108 & 41,22 & 198 & 75,57 \\
Timur & 0 & 0,00 & 1 & 0,38 & 1 & 0,38 \\
$\begin{array}{l}\text { Banjarnegara } \\
\text { Purworejo }\end{array}$ & 1 & 0,00 & 1 & 0,38 & 1 & 0,38 \\
Jumlah & 1 & 0,38 & 0 & 0,00 & 1 & 0,38 \\
\hline
\end{tabular}

Tabel 4 menyebutkan bahwa berdasarkan asal sampel hasil rif sensitif paling banyak daerah Magelang diikuti Kota Magelang, kemudian Kodya Jakarta Timur, Banjarnegara dan 
Purworejo. Hasil negatif dijumpai pada Magelang diikuti Kota Magelang, kemudian Wonosobo dan Kota Waringin Timur.

Penelitian gambaran hasil pemeriksaan TB paru metode TCM pada tersangka TB paru di RSUD Tidar Magelang dibagi menjadi tiga bagian, meliputi berdaarkan usia, jenis kelamin dan asal sampel pemeriksaan. Berdasarkan data penelitian tahun 2019 jumlah tersangka TB paru paling banyak adalah laki-laki. Hasil ini didukung penelitian Evita (2019) yang menyatakan jumlah pasien TB laki-laki lebih banyak dibanding perempuan. Menurut Jendra (2015) menunjukkan bahwa dari hasil survei prevalensi tuberkulosis menunjukkan bahwa prevalensi pada laki-laki lebih tinggi jika dibandingkan pada perempuan. Hal ini terjadi bisa dikarenakan laki-laki lebih sering terpapar faktor risiko dari penyait TB seperti minum alcohol, merokok, dan kurang kepatuhan minum obat.

Berdasarkan Tabel 3 disebutkan bahwa dalam penelitian ini hasil pemeriksaan TCM hanya ada rif sensitif dan negatif. Hasil TCM laki-laki maupun perempuan lebih banyak ditemukan hasil negatif dibanding hasil rif sensitif. Berdasarkan Tabel 2 hasil TCM kelompok lansia dan manula lebih banyak dijumpai hasil negatif dibanding hasil rif sensitif. Hasil TCM pada remaja dan dewasa lebih banyak ditemukan hasil rif sensitif dibanding hasil TCM negatif.

Penelitian ini menggunakan sampel pasien tersangka TB paru dengan pengobatan OAT (Obat Anti Tuberkulosis) kategori 1. Metode TCM memiliki sensitifitas dan spesifikasi yang baik sehingga keberadaan $M$. Tuberkulosis (MTB) dan resistensi terhadap rifampisin secara simultan dapat diidentifikasi. Hasil negatif memberi arti tidak terdeteksi resisten terhadap rifampicin sehingga pengobatan kategori 1 masih dapat diberikan. Hasil pemeriksaan TCM rif sen menunjukkan bahwa pasien masih sensitif terhadap OAT, sehingga pengobatan kategori 1 masih dapat diberikan.

Berdasarkan Tabel 4 sampel tersangka TB paru berasal dari berbagai daerah, termasuk luar provinsi yaitu DKI Jakarta dan Kalimantan Timur. RSUD Tidar Magelang berada pada jalur strategis yang dikelilingi wilayah Kabupaten Magelang dan di jalur persimpangan yang menghubungkan kota Semarang, Yogyakarta dan Purworejo sehingga mendapat rujukan sampel dari Banjarnegara, Purworejo dan Wonosobo.

Penelitian ini menggunakan data sekunder sehingga memiliki keterbatasan dalam mengetahui profil pasien. Data lamanya menjalani pengobatan, sosial ekonomi, kepatuhan minum obat dan status atau tipe kasus TB tidak seluruhnya lengkap tercantum.

\section{Simpulan dan Saran}

\section{Simpulan}

Berdasarkan usia yaitu remaja awal, remaja akhir, dewasa awal, dewasa akhir, lansia awal, lansia akhir, dan manula hasil TCM rif sensitif $0,76 \%, 11,45 \%, 9,54 \%, 7,25 \%, 5,73 \%$, $8,78 \%$ dan 3,82\%. Hasil TCM negatif $1,15 \%, 1,91 \%, 6,87 \%, 7,25 \%, 7,63 \%, 14,89 \%$ dan $12,98 \%$.

Berdasarkan jenis kelamin hasil TCM rif sensitif pada laki-laki $27,1 \%$ dan perempuan $20,23 \%$. Hasil TCM negatif pada laki-laki 31,3\% dan perempuan 21,37\%.

Berdasarkan asal daerah hasil TCM rif sensitif paling banyak daerah Magelang (34,35\%), Kota Magelang (11,83\%), Kodya Jakarta Timur, Banjarnegara dan Purworejo masing-masing 0,38\%. Hasil TCM negatif dijumpai di Magelang (41,22\%), Kota Magelang $(22,52 \%)$, Wonosobo dan Kota Waringin Timur masing-masing 0,38\%.

\section{Saran}

Perlu dilakukan penelitian lebih lanjut mengenai gambaran hasil pemeriksaan metode TCM dengan macam-macam tipe kasus TB. Serta penelitian dapat dilanjutkan lebih mendalam dengan metode analitik. 


\section{Daftar Pustaka}

Chairini, S., \& Widodo. (2020). Paru Profile of SGOT and SGPT levels in Patients with Pulmonary Tuberculosis Paru. Jaringan Laboratorium Medis, 02(01), 18-21.

Damayanti, M. (2020). Gambaran Kadar SGPT pada Pasien Tuberculosis Multidrug Resistant. Jaringan Laboratorium Medis, 02(02), 68-74.

Depkes RI. 2011. Pedoman Penanggulangan Tuberkulosis. Jakarta.

Evita Ruth. (2019). Uji Sensitivitas Dan Spesifisitas Genexpert Pada Penderita Suspek Tuberkulosis di Puskesmas Pancur Batu Kabupaten Deli Serdang. Poltekkes Medan. Karya Tulis Ilmiah. Poltekkes Kemenkes. Medan.

Hafidzah, Umi K. (2018). Model Skrining Massal Tuberkulosis dan Kasus Tuberkulosis (TBC) Paru di Lembaga Pemasyarakatan Kelas IIA Kabupaten Jember.

Hastuti, S. 2017. Hubungan Jumlah BTA dengan Kadar Gula Darah. Skripsi. Universitas Muhammadiyah. Semarang.

Jendra, FJ. (2015). Hubungan Faktor Risiko Umur, Jenis Kelamin dan Kepadatan Hunian dengan Kejadian Penyakit Tb Paru di Desa Wori Kecamatan Wori. Jurnal Kedokteran Komunitas dan Tropik, 3(2). 57-64.

Karlina, E., Widodo, \& Purlinda, D. E. (2019). Biokimia Mycobacterium Tuberculosis yang Diberi Perlakuan Obat Anti TB Isoniazid. Jaringan Laboratorium Medis, 1(2), $81-85$.

Kemenkes RI dan Ditjen P2PL. (2014). Pedoman Nasional Pengendalian Tuberculosis : Indonesia Bebas Tuberkulosis. Kementerian Kesehatan RI. Jakarta.

Kementerian Kesehatan RI. 2015. Standar Prosedur Operasional Pemeriksaan Mikroskopis TB. Jakarta. Dirjen Bina Upaya Kesehatan, Dirjen Pengendalian Penyakit dan Penyehatan Lingkungan.

Kementerian Kesehatan RI. (2017). Pelatihan Laboratorium Tuberkulosis Bagi Petugas di Fasyankes. Jakarta.

Kementerian Kesehatan RI. (2018). Tuberkulosis. Infodatin Pusat Data dan Informasi Kemenkes. Jakarta.

Novianti. (2019). Pemanfaatan Tes Cepat Molekuler (TCM) Genexpert Sebagai Alat Diagnostik Tb Paru di RSUD Wangaya Kota Denpasar. Jurnal Ekologi Kesehatan, $18(3): 135-148$. 